\title{
The Role of Cultural Value Orientations and Sexual Desire in Predicting Cybersex Behavior in Unmarried Young Adults
}

\author{
Virgon Hartoyo and Juneman Abraham \\ Department of Psychology \\ Bina Nusantara University
}

\begin{abstract}
The presence of Internet technology has opened up the emergence of new forms of sexual behavior, such as cybersex, which seems more massive nowadays. Regardless of the merits intended by the facilitating technology, in the context of Indonesian culture in which premarital sexual behavior (especially cybersex) is perceived as immoral, it is important to determine predictors of cybersex in order to minimize (or possibly eliminate) its negative impacts. This predictive-correlational designed study on 333 unmarried young adults participants (144 males, 189 females; mean of age $=20.724$ years old, standard deviation of age $=1.902$ years) employed the five dimensions of Hofstede's cultural value orientations (at individual level) and sexual desire as the predictors. The finding of this study was that only the long term orientation and sexual desire play significant roles in predicting cybersex, in positive ways; while four other cultural value orientations (power distance, uncertainty avoidance, masculinity/femininity, and collectivism/ individualism) are not able to predict it.
\end{abstract}

Keywords: cybersex, culture, sex, desire

Kehadiran teknologi Internet telah membuka kemungkinan munculnya bentuk-bentuk perilaku seksual baru, seperti siberseks, yang tampak semakin masif. Terlepas dari manfaat teknologi yang memfasilitasinya, dalam konteks kultur Indonesia ketika perilaku seksual pranikah (terlebih lagi siberseks) merupakan perilaku yang dipersepsikan sebagai tak bermoral, patut diketahui prediktor perilaku siberseks tersebut guna meminimalkan (bahkan bila mungkin mengeliminasi) dampak negatifnya. Penelitian korelasional-prediktif dengan partisipan 333 orang dewasa awal yang belum menikah (144 laki-laki, 189 perempuan; rerata usia $=20,724$ tahun, simpangan baku usia $=1,902$ tahun) ini menerapkan lima dimensi orientasi nilai budaya Hofstede (pada tingkat individual) dan hasrat seksual sebagai prediktor perilaku siberseks. Hasil studi ini menunjukkan bahwa hanya orientasi jangka panjang dan hasrat seksual yang berperan signifikan dalam memprediksi perilaku siberseks dalam arah positif. Adapun empat orientasi nilai budaya lainnya (jarak kekuasaan, penghindaran ketidakpastian, maskulinitas/femininitas, dan kolektivisme/individualisme) tidak mampu memprediksikannya.

Kata kunci: siberseks, budaya, seks, hasrat

Cybersex is a relatively recent sexual activity involving synchronous (takes place in real time), online (via the Internet) sexual interactions that occurs between two people or more (Shaughnessy \& Byers, 2013). Daneback, Cooper, and Månsson (2005) stated that cybersex is a sub-category of OSA (Online Sexual Activities; for nowadays example, see also "Durex Fundwear", 2013), which occurs when there are two or more people engaging in sexual conversation while

\footnotetext{
Correspondence concerning this article should be addressed to Virgon Hartoyo and Juneman Abraham, Department of Psychology, Faculty of Humanities, Bina Nusantara University, Jl. Kemanggisan Ilir III no. 45, Palmerah, DKI Jakarta 11480. Email: virgon_wen17@yahoo.com; juneman@binus.ac.id
}

online for the purpose of sexual pleasure as well as the possibility to masturbate. In his research on cybersex conducted in an online American chat room, Hamman (1996) found two types of cybersex behavior: First, each of the doers type the instructions and descriptions of erotica while masturbating; and second, the doers share erotic stories that excite themselves and the other user(s). It's not infrequent that a person is doing cybersex activities from the facilities provided by porn sites. Attwood (2010) mentioned that the Xtube site becomes the first porn site that provides paid webcam facilities for customers to communicate directly with amateur sex performer. Communication that was done 
could be through online chat, exchange of photos, also sexual performance (strip shows, sex shows, and sex chat lines). This phenomenon has also been experienced in Indonesia, although there are many people who are not yet familiar with the term "cybersex".

Cooper, Delmonico, and Berg (2000) explained that there are three causes that individuals do cybersex which are classified as Triple A engine, namely the accessibility (Internet access and facilities for accessing porn sites easily obtained by individuals), affordability (no need expensive fee to access the site), and anonymity (the user's identity cannot be detected in detail, so that other people do not know for certain who are the cybersex doers). In addition, there are two more categories that are considered as the factors of someone doing cybersex behavior, such as isolation (Internet provides space for a person to engage in the desired activity without direct contact with another person) and fantasy (individuals are free to choose the desired partner criteria so that they are able to feel satisfaction in their sexual activity) (Carnes, Delmonico, \& Griffin, 2007).

The Griffin-Shelley's (2003) and Bleakley's (2014) systematic review showed serious negative impacts on a person's psychosocial life, such as online sex addiction, being potential victim of online sex related crime, women being dehumanized, being sufferer of intense stalking or other online jeopardizing communications so that the study about cybersex should be deepened further. There are other negative effects for the cybersex actors; they could prefer to have multiple sex partners in the real world because they are used to being in the cybersex situation where they can have multiple partners (Daneback, Cooper, \& Månsson, 2005). Attwood (2009) found the reality that the cybersex doer tends to be dishonest about him/herself about what to tell to his/her cybersex partner. The doers tend to condition or situate themselves (self and persona) in accordance with the partner. For example, an older man will tend to lie about his age when knowing that his online partner prefers to speak to or perform sexual acts with younger men.

Nevertheless, cybersex has certain functions that are considered "positive", such as avoiding the risk of sexual diseases being transmitted, developing knowledge about sexuality, improving sexuality (Hald \& Malamuth, 2008), and improving the quality of sexual relationships in real life (Grov, Gillespie, Royce, \& Lever, 2011). Cybersex can indeed be a facilitating channel of sexual desire. Grov et al. (2011) provide data that cybersex has a more positive impact related to intimacy with the partner, but only if the cybersex partner is the actual spouse in the real world.
Tan (2009) stated that Internet has become a means to seek sexual partners and experiences. One of the international gay Internet sites, Planet Romeo, indicated that Asia is a continent with the second largest numbers of posts (text, audio, audio-visual) (26.37\%) on the site after the Europe $(61.57 \%)$ (Tan, 2009). According to a survey done by Male Emporium magazine in Indonesia ("Analisa Polling," 2006), 45.95\% of the surveyed Internet users have done cybersex and most of them begin to know Internet in the age range of 20-25 years old. The performer of cybersex in this present research are young adults at the age of 18 to 25 years. Based on the life span of sexual development, the person is relatively free from control of his/her parents or has a more personal freedom as well as increasing experiences in searching identity in terms of love, work, and way of life, and generally they are more inclined to have a number of sexual partners. This period is also the average age of marriage (King, 2011).

Beside age, culture is also often associated with sexual activity. It is seen from many studies linking sexual behavior with cultural elements. Research conducted by Rodríguez-Arauz, Mealy, Smith, and Diplacido (2013), for example, showed that cultural differences affect the knowledge and perceptions that ultimately impacted on behavior in sexual activity. For example, in Costa Rica in which the culture is associated with Catholic values and the perseverance of collectivity and harmony, the people tend to (1) consider behaviors such as oral sex, foreplay, and phone sex already as "sex," although coitus does not happen, (2) oppose sex outside marriage, and (3) allow the overt sexual material more for men than for women. In the United States in which the culture is more tolerant against uncertainty, people are more accepting their sexual behaviors as diverse though these behaviors are not focusing on emotional affinity.

G. Hofstede, Hofstede, and Minkov (2010) stated that culture is an overall pattern of thought, feeling and action of a specific social group ("collective mental programming"), which distinguishes itself among other social groups. Therefore, culture is an abstract idea about things that are considered to be true, good and desirable by a social collectivity. According to Hofstede, culture has five dimensions, of which each category has a unique characteristic (Hofstede et al., 2010). Culture is closely associated with the history of the inheritance patterns of certain symbol containing meanings, as well as the way people communicate, preserve the culture, and shape the knowledge and attitude of his/her life (Hofstede et al., 2010). In their 
study, Yoo, Donthu, and Lenartowicz (2011) transformed all five of Hofstede's cultural dimensions measurement: Power Distance, Individualism/ Collectivism, Masculinity/Femininity, Uncertainty Avoidance, and Term Orientation (Long versus Short), into individual level. Based on the cultural dimensions, the authors of this present study formulate a number of hypotheses.

In a high power distance culture, individuals have a dependency on people who have a higher position. The relationship tendencies in social groups, that is between men and women, are more autocratic, asymmetric, and paternalistic. Seen in the context of sexual relations in hetero-sexual couples, in the social reality, men tend to be able to do coercing conduct in sexual inter-course, because a man is considered to be more powerful than a woman (Ubillos, Páez, \& González, 2000), which is criticized by the feminism movement. The disagreement between women and men about sex is also obvious. Cybersex is not considered as a form of infidelity by men, but for women it is considered as such (Knox \& Schacht, 2013). Cybersex activity is regarded as a solution that is consistent with the dominance of men over their sexual behavior. Cybersex activities are deemed beneficial to prevent someone from being infected by sexual diseases, especially for men who have multiple partners. Thus, the first hypothesis of this study (H1) is that there is a positive correlation between the value of power distance and cybersex behavior, such that people who have a higher degree of cultural power distance will be more likely to engage in cybersex.

Individualism is a cultural trait that describes the adherence to act as a unique individual rather than as a member of a group (Hofstede et al., 2010). In this culture, sexual activity has a personal freedom nuance and has the meaning that is based on personal enjoyment (Michael et al., as cited in Rodríguez-Arauz et al., 2013). On the contrary, collectivism shows the nature of culture that describes a strong social framework in which individuals expect others in their group to maintain and protect them. The most important value in this culture, among others are filial relationships (respecting parents, obedient to parents, and honoring the ancestors), the purity of the women, and love for the homeland (Hofstede et al., 2010). In the context of purity in women, chastity in the meaning of sexuality is often defined as a woman's virginity. Virginity is generally attributed as the intact hymen on a woman's vagina (Tai, 2015). Cybersex can be used as a media for the sex doers in their sexual activity without direct physical contact and thus minimize the potential for "losing virginity". So the second hypothesis of this study (H2) is that the higher the level of collectivism cultural dimension (or the lower the level of individualism dimension) in a person, the higher the individual's cybersex behavior likelihood.

In the masculine cultures, sex is often regarded as an indicator of achievement (Hofstede et al., 2010; Ubillos et al., 2000). The aim is more on the intercourse rather than the relationship (Michael et al., as cited in Rodríguez-Arauz et al., 2013). Therefore, cybersex is not considered as a real sexual performance due to the absence of a penetration in these activities. In the feminine cultures, people are more concerned with other people's quality of life compared with gaining power as well as material success (Hofstede et al., 2010; Ubillos et al., 2000). Sex is regarded as part of a relationship, as a bond to strengthen a relationship (Hofstede et al., 2010). In this culture, cybersex can be considered as a shaping of commitment (Rodríguez-Arauz et al., 2013). So the third hypothesis of this study (H3) is that the higher the level of the femininity cultural dimension (or the lower the level of masculinity dimension) in a person, then the higher the person's cybersex behavior likelihood.

The uncertainty avoidance is a concept of cultural dimensions that reflects individual's anxiety level about the uncertainty of the future. To overcome anxiety, people turn to technology, regulations and rituals (Swindler, 2007; Hofstede et al., 2010; Westrum \& Adamski, 2010). Technology will reduce some of the uncertainty states by creating short-term predictability. Regulations will control things that are dynamically moving. Rituals help the individual to accept the uncertainty that can not be avoided or anticipated. In addition, as a result of adherence to social norms on uncertainty avoidance cultures, conventional offline sexual behavior outside of marriage is deemed as inappropriate action because it transgresses the social norm (Ubillos et al., 2000). People will then promptly look for certainty in the sexual field by escaping the forms of non-conventional sexual behavior, such as through cybersex. Thus, the fourth hypothesis of this study (H4) is that if uncertainty avoidance is higher, then the probability of cybersex activities will tend to increase.

Short-term orientation is related to the achievement of immediate satisfaction focused on results that can be enjoyed at once and on the awareness about the importance of compromise (Hofstede et al., 2010). Cybersex is a sexual activity that can be accessed easily and can directly be reachable (Cooper et al., 2000). In 
other words, cybersex is a practical sexual activity, and the individual can directly feel quick sexual need fulfillment. It is suspected that cybersex is one of the reasonable choices in the individuals' short-term orientation mindset to meet the sexual needs without having to consider about distances, times, and locations. Thus, the higher level of short-term orientation of cultural dimension, the higher the individual's cybersex behavior. In contrast, individuals who have a long-term time orientation tend to postpone their needs (delayed gratification) such as in doing sexual activity. So the fifth hypothesis of this study (H5) is that the higher the level of short-term orientation dimension (or the lower the level of long-term orientation dimension) within the individual, then the individual's cybersex behavior likelihood will tend to increase.

Another variable that is hypothesized to predict the cybersex behavior is sexual desire. Sexual desire is often interpreted as an interest to engage in sexual activity, or desire level of approaching (or avoiding) sexual behavior; sexual desire can be referred to as libido (Leiblum, 2007; Levine, 2003). According Pfaus and Scepkowski (2005), libido is the fluctuation of sexual motivation in every organism. In fact, there is no universal definition that can describe the sexual desire (DeLamater \& Sill, 2005). This is due to two different viewpoints. First, sexual desire is regarded as emerging from the innate energy. Second, the viewpoint that emphasizes that sexual desire as not merely a biological force but a function of the cognitive strength and/or emotional experiences such as hope or wish, or having relational dimensions. In accordance with Heider (as cited in DeLamater \& Sill, 2005), desire is highly motivational and subjective. Levine (2003) believed that sexual desire is the result of interaction between (1) the neuroendocrine systems, which has a biological basis; (2) wish involving sociocultural expectations for sexual behavior; and (3) the psychological, motivational processes in sexual behavior. In the present study, the authors used a biopsychosocial perspective that sexual desire is a function of biological influence, psychological and social influences (DeLamater \& Sill, 2005; Spector, Carey, \& Steinberg, 1996). In the social aspect, for example, an individual or couples with higher incomes have access to health care and activities that can maintain physical and general mental health, meanwhile better health is more likely to increase sexual desire (as cited in DeLamater \& Sill, 2005).

Social institutions and social interactions as well as social programs can also affect sexual desire (Schwartz \& Rutter, 1998). For example, (1) popular movies and television programs that focus on sexual desire can bring and stir sexual imaginations and drives in a society; (2) how we perceive or appreciate our biological sexual experience, whether as fun or as a "burden", is influenced by the social sexual rules; (3) in some societies, ejaculation that is considered healthy is that of high frequency and quick, while in other communities healthy ejaculation is that experiencing delay as long as possible; as well as (4) recommenddations for the use of high heels for females to succeed in luring males, although detrimental to women from the physical aspect, is the social construction of female

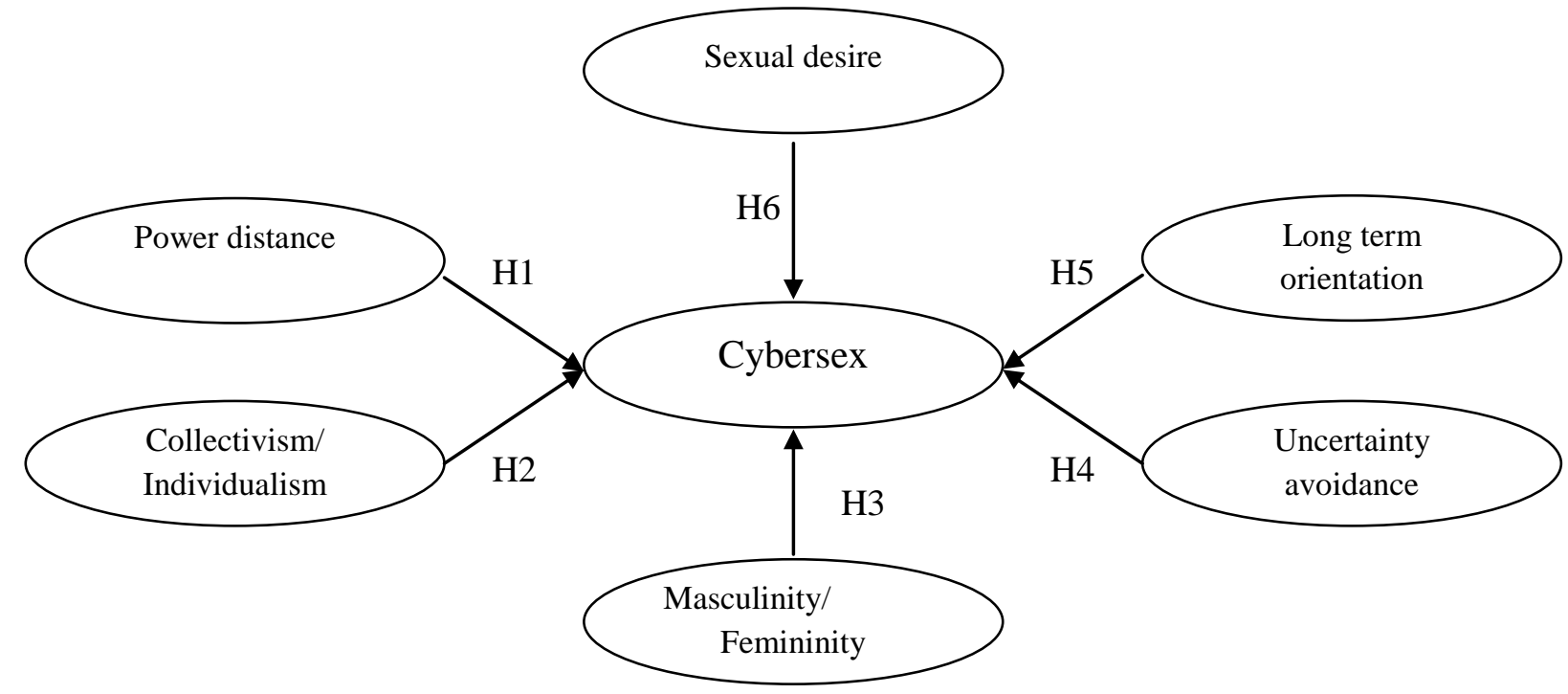

$\mathrm{H} 7$

Figure 1. Hypothetical model depicting the predictors of cybersex behavior. 
sexiness determined by the political agenda of the dominant group (Schwartz \& Rutter, 1998).

High levels of sexual desire will increase sexual appeal to men and women (Lippa, 2006). Cybersex can be used to facilitate a person's sexual desire, especially for individuals with high sexual desire. In terms of the young adults' characteristics in their sexual development which is in search of identity in terms of love, they are more inclined to have multiple sexual partners (King, 2011). In that process, it can be assumed that sexual desire becomes one of the variables that have a prominent role in their development period. Therefore, the sixth hypothesis of this study (H6) is that the higher an individual's sexual desire, the higher the probability of his/her cybersex behavior will be.

By integrating all of the previous hypotheses, from the first (H1) to the sixth (H6), then the author hypothesized, "There is a theoretical model that can be used to explain the likelihood of cybersex behavior, as presented in Figure 1" (H7).

\section{Method}

\section{Participants and Design}

Participants of this study were 333 unmarried young adults (144 males, 189 females; Mean of age $=20.724$ years old, Standard Deviation of age $=1.902$ years), who were recruited with convenience sampling technique. The tryout phase of research instrument was conducted on 80 people outside of the field research participants. Data of trial research instruments were analyzed to generate the Cronbach's Alpha index (criterion of reliability: Alpha $\geq .600$ ) and to generate the corrected index of item-total corre-lations (items valid criteria: correlations $\geq .250$ ).

This study's design is predictive correlational design. Predictors (independent variables) in this study were the sexual drive and five dimensions of Hofstede's cultural value orientations. The criterion variable in the study was cybersex behavior. Data were analyzed using logistic regression techniques, because the criterion variable was a variable in the binominal scale while the predictor variables were variables in the interval measurement scale.

\section{Materials and Procedures}

The measurement instrument of cybersex behavior was adapted from Lifetime Cybersex Experience Ques- tionnaire (multi-item) developed by Shaughnessy and Byers (2013). The instruction of this measurement device is as follows:

"People do a lot of different sexual and/or intimate things on the Internet that include other people. People also do these kinds of activities with different kinds of partners. Below is a list of activities that some people do, and that you may have experienced. For each activity, please check the box if you have EVER done the activity with a primary partner, a known nonpartner, and/or an unknown other."

Some example items of the eight points listed are: (1) Created a story based on sexual fantasies with another person where you each add to the story as it goes, (2) Described specific sexual acts you would do to another person as if it was happening, (3) Described your sexual fantasies and/or sexual desires to another person, (4) Behaved sexually for another person to watch, and (5) Described in detail a sexual activity or sexual scene back and forth with another person as if it was happening.

If the participant claimed that he/she had done one or more of the eight points of the behavior, then he/she was given a score of 1 . If the participant claimed he/she never did them at all, then he/she was given a score of 0 . The reliability of this measurement instrument is 0.9 (Shaugnessy \& Byers, 2013).

To measure the five dimensions of Hofstede's culture values at the individual level, the measurement instrument used was CVSCALE developed by Yoo et al. (2011). Researchers also added items to the measurement instrument for each dimension. Additional items of Power Distance were derived from the article by Ly (2013). Additional items of Uncertainty Avoidance were derived from the research by Altuncu, Aktepe, and Islamoglu (2012). Additional items of Individualism/ Collectivism were derived from Communal and Exchange Orientation Scales derived from the article by Chen, Lee-Chai, and Bargh (2001). Additional items of Masculinity/ Femininity were derived from the article by Snell (2013). Additional items of the long-term orientation dimension were derived from Gul (2013). On average, the authors added two to four items for each of the CVSCALE scales.

Sample items of Power Distance dimension are: "People in higher positions should make most decisions without consulting people in lower positions", "People in higher positions should avoid social interaction with people in lower positions", and "When an employer asks the opinion of subordinates before making a final decision, then he will lose the respect of his subordinates". 
Sample items of Uncertainty Avoidance dimension are: "It is important to follow closely instructions and procedures", "Standardized work procedures are helpful", and "I feel depressed when I could not predict a result". Sample items of Collectivism dimension are "Individuals should only pursue their goals after considering the welfare of the group", "Individuals should stick with the group even through difficulties", and "I believe that one should get out of the habit to help others". Sample items of Masculinity dimension are: "Solving difficult problems usually requires an active, forcible approach, which is typical of men", "I usually do not discuss my feelings and emotions with others". Sample items of Long Term Orientation dimensions are "I manage money very carefully", "I have a long-term planning", "I work hard for success in the future", and "When I buy a product, I try to consider how the impact on the environment and other consumers".

The response options ranged from Strongly Disagree (score of 1) to Strongly Agree (score of 6). Reliability and validity test results showed the following: Power Distance measurement instrument has a Cronbach's Alpha index of .805 , with the corrected item-total correlations ranged from .269 up to .708 , without any items that need to be eliminated. Uncertainty Avoidance measurement instrument has a Cronbach's Alpha index of .648, with the corrected item-total correlations ranged from .333 up to .422 , by eliminating three items. The measurement instrument of Long Term Orientation has a Cronbach's Alpha index of .744, with the corrected item-total correlations ranged from .289 to .642 , without any items that need to be eliminated. Masculinity measurement instrument has a Cronbach's Alpha index of .844, with the corrected item-total correlations ranged from .466 to .761 , by eliminating one item. Collectivism measurement instrument has a Cronbach's Alpha index of .816 , with the corrected item-total correlations ranged from .300 to .714 , without any items that need to be eliminated.

In order to measure sexual desire, the measurement instrument used was Sexual Desire Inventory-2 (SDI-2) which was constructed by Spector, Carey and Steinberg (1996). SDI-2 measure two aspects of sexual desire, namely: First, the dyadic sexual desire, measuring the sexual desire from the sexual activity conducted with a (potential) partner/spouse; and second, solitary sexual desire, measuring the sexual desire from the sexual activities undertaken by oneself or without the involvement of anyone else.
There were 14 items that aimed to measure sexual desire. Sample items are (1) "During the last month, how often would you have liked to engage in sexual activity with a partner (for example, touching each other's genitals, giving or receiving oral stimulation, intercourse, etc.)?" (2) "During the last month, how often would you have liked to behave sexually by yourself (for example, masturbating, touching your genitals etc.)?" The response options ranged from Not at all (score of 0 ) to More than once a day (score of 7). Examples of other items: (1) "When you spend time with an attractive person (for example, at work or school), how strong is your sexual desire?" (2) "When you are in romantic situations (such as a candle lit dinner, a walk on the beach, etc.), how strong is your sexual desire?".

The response options ranged from No Desire (score of 0) to Strong Desire (score of 7). Reliability and validity test showed a Cronbach's Alpha index of .940 with corrected item-total correlations ranged from .455 to .874 , without any item that needs to be eliminated.

\section{Results}

Descriptive statistics of participants are as follows: The participant's domiciles were: Jakarta (130), Bogor (47), Depok (44), Tangerang (59), and Bekasi (53). None of the participants were married. The composition of the educational level of participants was: Bachelor/Stratum 1 (103), Senior High School (222), Master/Stratum 2 (5), Junior High School (2), and Elementary School (1). A total of 310 participants had their own always-on-accessible Internet, and 23 participants did not have it. A total of 284 participants felt that Indonesia does not give them freedom to have sexual expression, and 49 participants did feel the freedom.

Multiple logistic regression results showed that: Hosmer \& Lemeshow's $\chi^{2}(d f=8)=9.051 ; p=.338$ $(p>.05)$. It represents the fitness of the hypothetical model to the data. H7 was supported by empirical data. Power distance $(B=-0.011 ; S E B=0.023 ; p>$ $.05)$ was not able to predict the cybersex behavior likelihood (see Table 1). Similarly, collectivism $(B=$ 0.037; SE $B=0.027 ; p>.05$ ) did not have predictive power toward the cybersex. Masculinity $(B=0.045$; $S E B=0.032 ; p>.05)$ and Uncertainty Avoidance $(B$ $=0.031 ;$ SE $B=0.037 ; p>.05$ ) also could not predict the likelihood of sexual behavior. 
Table 1

Multiple Logistic Regression Analysis Predicting Cybersex Behavior $(N=333)$

\begin{tabular}{lccccc}
\hline Predictor & $B$ & $S E B$ & $\begin{array}{c}\text { Wald's } \chi^{2} \\
(d f=1)\end{array}$ & $p$ & $\begin{array}{c}e^{\beta} \\
\text { (odds ratio) }\end{array}$ \\
\hline Power distance & -0.011 & 0.023 & 0.213 & .644 & 0.989 \\
Collectivism/individualism & 0.037 & 0.027 & 1.954 & .162 & 1.038 \\
Masculinity/femininity & 0.045 & 0.032 & 1.964 & .161 & 1.046 \\
Uncertainty avoidance & 0.031 & 0.037 & 0.690 & .406 & 1.031 \\
Long term orientation & -0.057 & 0.029 & 3.983 & .046 & 0.944 \\
Sexual desire & 0.013 & 0.006 & 4.580 & .032 & 1.013 \\
\hline
\end{tabular}

Note: $S E=$ standard error

Long term orientation $(B=-0.057 ; S E B=0.029 ; p$ $<.05)$ was able to predict cybersex behavior in the negative direction. The higher a person's long-term orientation, the lower his/her cybersex behavior probability; the higher a person's short-term orientation, the higher his/her cybersex behavior likelihood (see Table 1).

Sexual desire was able to predict the cybersex behavior $(B=0.013 ; S E B=0.006 ; p<.05)$. The higher a person's sexual desire, the higher his/her cybersex behavior will be.

The value of Cox \& Snell's $R$ Square is 0.038 , and Nagelkerke's $R$ Square is 0.055 . If both of these values are multiplied by $100 \%$ then they become $3.8 \%$ and $5.5 \%$. This suggests that the contribution of the Hofstede's five cultural dimensions at the individual level and sexual desire levels to cybersex behavior are approximately $3.8 \%$ to $5.5 \%$.

From the results, it can be seen that $\mathrm{H} 1, \mathrm{H} 2, \mathrm{H} 3$, and $\mathrm{H} 4$ were not supported by empirical data, whereas H5 and $\mathrm{H} 6$ were supported by empirical data.

\section{Discussion}

This study aimed at investigating the cultural predictors (five Hofstede cultural value orientation at the individual level) and personal predictor (sexual desire) of cybersex behavior. There were seven hypothesis proposed in a hypothetical model (H7). Four variables that was hypothesized to have positive predictive correlations with the cybersex behavior are Power Distance (H1), Collectivism (H2), Uncertainty Avoidance (H4), and Sexual Desire (H6). Two variables that was hypothesized to have negative predictive correlations with the cybersex behavior are Masculinity (H3) and Long term Orientation (H5).

This study found that short-term time orientation could predict cybersex behavior in a positive way. Buss and Schmitt (as cited in Hatfield, Luckhurst, \&
Rapson, 2010) stated that a man who has short-term relationships orientation tends to have sexual partners (that are considered beautiful, fertile, reproductively healthy, and not conservative) as much as possible. The meaning of "as much as possible" connote to not committed to a particular relationship. While a woman who has short-term relationships orientation will seek "expensive" exchange for the sexuality they "offer", although women also kept the hope to be able to attract men who can be invited to establish a long-term relationship. Examined carefully, the needs of these men and women can be well facilitated via cybersex (e.g. for women, by becoming camgirl; Bleakley, 2014). Starcevic and Aboujaoude (2015) stated that cybersex contains "irresistible appeal of short-term sexual pleasure" (p. 98), even though people may be unaware of the negative long-term effects, which may include finance, romance, and legal issues. Mechanisms that occur in the mind of short-term oriented people can be explained by using the psychological mechanism of Owens, Behun, Manning, and Reid (2012) as follows: In young adults who also became participants in this present study, delayed gratification (which is often required in long-term orientation) does not work when confronted with the urgency to satisfy the tension. The tension used to be generated by the sexual-emotional stimuli produced by cybersex images and becomes salient in the mind of the youth. Physiologically, the cognitive control of the frontal cortices on sexual cravings dominated by limbic structures of the early adults do not work as expected.

This study also found that collectivism/individualism was not able to predict the cybersex behavior. It means that neither collectivism or individualism may facilitate or inhibit cybersex behavior. The author examined that the "anonymity" construct had made the relationship between collectivism/individualism and cybersex behavior more complicated. Farrall (2012) explained that the anonymity in the East Asia region, one that 
has shared cultures with Indonesia, has two natures. First, anonymity serves as a source of personal privacy (that supports individualism), as found in China. Second, anonymity works as a source of adhesive affiliation and intimacy (that supports collectivism), especially in small-scale social networking, as existed in Japan. Anonymity is one of the fundamental features of cybersex, and it is associated with (1) safety, (2) greater probability to obtain reachable sexual partners, and (3) the facility to cut off contact in sexual relationships at any time without being on-track (Ross, Rosser, \& Stanton, 2004).

Interaction between individualism and anonymity can strengthen cybersex behavior if the goal of cybersex is sexual gratification. Interaction between individualism and anonymity can also weaken cybersex behavior if cybersex is considered only as a game that does not have a deeper meaning. Interaction between collectivism and anonymity can strengthen cybersex for it accelerates intimacy. Interaction between collectivism and anonymity can also weaken the cybersex when cybersex is viewed as having the potential to fertilize affair that cannot be accepted by the collective norm. Those mechanisms were summarized by Alison (2011) as the "Paradoxes of cybersex." This could explain why a predictive correlation between collectivism/individualism and cybersex behavior was not found in this present study.

This study found that masculinity/femininity was not able to predict the cybersex behavior. Two natures of masculinity maight cause it. Michael (2012) found through his empirical research that cybersex was correlated with risk-taking activities, specifically risky sexual behavior, and that masculinity may play a role in risk-taking behavior. Although, cybersex has less or even no risks of sexually transmitted disease, unplanned pregnancy, sexual objectification of woman, and shame or other unpleasent feelings generated from sexual communications (Döring, 2000), because of its natures of no direct physical contact, woman liberation (in one feminism perspective), and anonimity, it is known that cybersex involvement has compromised or put in preil of one's productivity, health (compulsion, addiction risks), personal life satisfaction, and relationship satisfaction (Rimington \& Gast, 2007; Whitbourne, 2014). In fact, masculinity is associated with riskseeking behavior, which is connected by a physiological explanation in the form of testosterone hormones existence in masculine people (Jia, van Lent, \& Zeng, 2014), that supports cybersex behavior. However, if the masculinity characteristics (for example success in career, marriage, reproductive, and financial; Williams, as cited in Williams, Lyons, \& Ford, 2008) are confronted with the stakes of productivity and life satisfaction of cybersex as stated above, then masculinity no longer supports cybersex behavior.

In addition, femininity can also support cybersex. McCallum (1999, p. 87) stated, “... technology can amplify individual autonomy by providing the space to explore new identities or to engage with others in new ways." As it is known, "engage with others" is often considered as feminine traits or needs, although Jordan, Kaplan, Miller, Stiver, and Surrey (1991, p. 149) has reminded us, "Men also need to be attached to others, to engage with others, ..., but they have considerable difficulty acknowledging their needs openly. Men are, in fact ... also project them as undesirable qualities onto women." Based on these descriptions, it appears that both masculinity and femininity can both support and not support cybersex. This is why there is no correlation between masculinity/femininity and cybersex.

This study found that there is no predictive correlation between the power distance and cybersex. In one aspect of cybersex, namely content, it was found that men are often seen as the dominant party while women appear as the submissive party. Cybersex material themes (e.g. visual images) such as sperm ejaculated by the male to female faces, where women seem to enjoy it, as well as the exploitation of women's bodies in the control of men, have been reinforcing the high power distance between the parties involved in cybersex, that men and women are not in the equal position (Garlick, 2011; Gorman, Monk-Turner, \& Fish, 2010). In that kind of cybersex, romance is reduced to erotica (McCallum, 1999), and it is strengthening the stereotype of male power in defining sexuality unilaterally.

However, in another aspect, it is believed that the body is "not present" in cyberspace, and if it is present, people can lie about their attributes. Identity (e.g. gender identity, ethnic identity, religious identity, national identity) and its status are no longer important. Technology is reducing the transmission of social cues (Kersten, Koeszegi, \& Vetschera, 2003). As a result, power distance becomes smaller. For some parties, this explanation in a "cybertopian" (Magnet, 2003) nuance is not realistic. In other words, they believed that a person's identities still exist and are projected in an online activity so that the power distance is not as dramatic as it undergoes elimination. Another alternative explanation is that cyberspace allows people to explore each other's identity. Encounter in cybersex activities is one that could be anticipated by studying first the self-presentation of the counterpart party (e.g. via the social media profiles). 
Walther (as cited in Tong, 2008) found that such anticipation strengthened the similarity and intimacy. Such things can also reduce the power distance between the negotiating parties in cybersex activities. As evident in these explanations, both high and low power distance can be compatible with cybersex. This is supposed to influence the absence of correlation between power distance and cybersex.

This study found no predictive correlation between uncertainty avoidance and cybersex. Although there is no research that specifically connects uncertainty avoidance and cybersex, Garcia and Yang (2006) through their empirical research have found indications that uncertainty avoidance (UA) is able to predict attitudes toward sex in advertising. People with low UA have more tolerant and positive attitudes towards advertisements containing sexual appeals. Whereas people with high UA have negative attitudes toward that kind of advertisement because it is not compatible with their cultural norms. It can be applied to cybersex; people with high UA will have lower behavior related to sexual nuance in the cyberspace.

However, it can not be denied that uncertainty avoidance can support cybersex behavior, because cybersex offers "safer sexual behavior" as previously described (e.g. minimal even zero risk toward sexual transmitted diseases), whereas among people with high levels of uncertainty avoidance, "safety requirements of (the) individuals are more tangible" (Demir \& Okan, as cited in Seymen and Bolat, 2010, p. 12). Those two paradoxical natures of UA in relation to sexual behavior could influence the absence of correlation between UA and cybersex.

This study found that sexual desire was able to predict cybersex behavior in a positive way. Sexual desire is "a complex interplay of motives, perceptions, and sensations that neither easily fits into the standard sexual cycle nor serves an exclusively sexual function" (Štulhofer, Ferreira, \& Landripet, 2014, p. 230). Štulhofer et al. (2014) found that sexual desire was positively correlated with emotional intimacy. They explained that these findings countered the "traditional speculation" in clinical psychology. The speculation says that sexual desire decreases when emotional intimacy increases (especially in men) because the existence of sexual desire is sustainable when the "perception of otherness" of their sexual partners are high (Perel, as cited in Štulhofer, 2014); that intimacy (decreased perception of otherness) lessened sexual desire.

In addition, Štulhofer et al. (2014) explained that the change of cultural and social norms has allowed or enabled the sexual desire expressions in intimacy nuanced for men. The norm changes have also replaced the meaning of intimacy which is becoming more and more important (not just physical desire fulfillment) in men. This norm change, in Indonesia, has already been foreseen by Kartajaya (2006), as follows: "The technology (like the Internet) make people become 'more human,' can stimulate human emotions and facilitate human expression and commu-nication with the surrounding environment" (p. 12). It is therefore understandable if emotional intimacy for both men and women now becomes an important construct that contributes to their sexual desire.

If the facts about the empirical positive correlation between emotional intimacy and sexual desire above are integrated with this study results (that found a positive predictive correlation between sexual desire and cybersex behavior), it will bring up the proposition that cybersex could be used to fulfil the emotional intimacy needs for both male and female young adults. This proposition is supported by empirical research findings of Young, Cooper, Griffin-Shelley, O'Mara, and Buchanan (2000) that cybersex providing increasingly private spaces have contributed an opportunity for the users or activists to share the most intimate feelings although the sharing is done with non-significant others. One reason for it is as follow, "Soon typed messages passing along the computer screen carry with them emotional significance that often precedes more erotic dialogue between online friends, which may blossom into virtual adultery." (Young et al., 2000). Sajo (2015) also found that cybersex has become producer of affects. The meaning of the integration of those research's findings is that if a high sexual desire is not satisfied in real life or offline situation, it will "flow" (compensatorily) through cybersex behavior, because cybersex also excites the intimate feeling. This is supported by Ben-Ze'ev's explanation (2004) stating that in an online personal relationship, although people involving in it have never met and might be a stranger to each other (in various levels), they are also, paradoxically, "close" to each other because they "share intimate information and common dreams .... becoming emotionally close to each other" (p. 28). To maintain the continuity of cybersex, the involved parties are responsive and sensitive to one another (Ben-Ze'ev, 2004), and this facilitates the actualization of one's sexual desire.

\section{Limitations and Directions for Future Studies}

To the methodological level, this study has not distinguished cybersex behaviors, whether they were done with a primary partner, a known nonpartner, and/or an 
unknown other, as stated by Shaughnessy and Byers (2013), as well either it is done coercively or negotiatively. Further research needs to be more detailed in investigating the predictors of cultural value orientation in relation with the rich variation types of cybersex behavior.

In addition, this research has not investigated yet the interaction between the cultural value orientation variables and other contextual variables in predicting the behavior of cybersex. As indicated by Kirkman, Lowe, and Gibson (2006), studies that try to find out the main effects of cultural value orientations are advisable to integrate contextual moderating variables (for example: demographic features, such as age, urban versus rural living, sex, religion; cf. Weinstein, Zolek, Babkin, Cohen, \& Lejoyeux, 2015, as well as socioeconomic status, length of the online activities, the major of study, and ethnicity), because by the integration, the results can be more varied and more having theoretical significance. This research also needs to incorporate explicit theoretical chains that indicate the psychological processes involved from the cultural value orientations to the occurrence of outcome variable so that we can understand the complex dynamics of cybersex behavior. Psychological variables that might play roles in these chains, as described in this Discussion section, could be employed as contextual mediators for further research. Multilevel cultural analysis (individual vs. group vs. organizational vs. national) is also recommended in order to provide advice for richer intervention toward variables playing role in cybersex tendencies.

\section{Conclusion and Implications}

This study concluded that of the five individual's cultural orientations, only term orientation is able to predict cybersex behavior. The inability of power distance, uncertainty avoidance, collectivism/individualism, and masculinity/femininity in predicting the cybersex behavior is more due to the paradoxical effects of these orientations, which can simultaneously support and reduce cybersex. Furthermore, sexual desire also can predict cybersex behavior.

The implication of this study is that in order to prevent the negative consequences of cybersex, as it is considered as another immoral form of premarital sex behavior (Webster, 2010), the importance of under-standing and strengthening the meaning of long-term orientation needs to be invested in the very early stage of human's development. If we want to save our youth from the damaging effects of cybersex, there needed to be systematic efforts done at the personal level, structural level, or cultural level.

The method that can be proposed is to establish, educate, or train willpower (the ability to impede immediate desire gratification), such as the training of the temptation avoidance ("out of sight, out of mind"), implementation intention ("if-then" statements in our mind to control our future behavior), regular willpower exercise with physical exercise (American Psychological Association, 2015, p. 13), knowing, coping with, and overcoming any psychological pains, being vigilant of and managing any rationalization (Pagoto, 2012), distraction training, using abstraction similar to "hallucinatory image" of objects of desire (Shook, 2014).

On a cultural level, there should be efforts to reduce the "instant culture". Urgency of this reduction is reflected in the following statement: "The 'instant culture', which main message is 'carpe diem', speedy communication and sexualization of life, shapes the identity of young people and their lifestyle" (Melosik, as cited in Potyrala, 2011, p. 96). In order to reduce the negative impact of instant culture, which according to the results of this study is associated with cybersex behavior, efforts to create psychological and social buffers need to be done so that a person is not absorbed in the instant culture. In addition to exercising the gratification delay, at the cultural level, Juneman (as cited in "Bertahan di", 2014) stated that the public can:

"multiply spaces for reflection and expression, such as art activities, spiritual activities, or other creative activities which essentially creates 'shelter halts' that can break the speed of the life flow. As such, our robbed consciousness become recovered and whole again, and we go back controlling ourselves." (p. 88)

\section{References}

Alison, R. (2011). Anonymity fuels the paradoxical growth of cybersex. Retrieved from http://www.winni pegfreepress.com/opinion/analysis/anonymity-fuels-theparadoxical-growth-of-cybersex-134379333.html

Altuncu, Y., Aktepe, S. Ö., \& Islamoglu, G. (2012). Preliminary study for the development of uncertainty avoidance instrument in Turkey. Journal of Business, Economics \& Finance, 1(4), 34-48.

American Psychological Association. (2015). What you need to know about willpower: The psychological science of self-control. Retrieved from http://www. apa.org/helpcenter/willpower.pdf

Analisa polling: Percintaan alam maya. (2006, July 18). Male Emporium. Retrieved from http://cyberman. 
cbn.net.id/cbprtl/cyberman/detail.aspx ?x=Survey\& $\mathrm{y}=$ cyberman $|0| 0|14| 24$

Attwood, F. (2009). Deepthroatfucker and discerning adonis: Men and cybersex. International Journal of Cultural Studies, 12(3), 279-294. http://dx.doi.org/ 10.1177/ 1367877908101573

Attwood, F. (Ed.). (2010). Porn.com: Making sense of online pornography. New York: Peter Lang.

Ben-Ze'ev, A. (2004). Flirting on and offline. Convergence, 10(1), 24-42.

Bertahan di tengah serbuan budaya instan. (2014, April). Media Kawasan, April 2014, pp. 86, 88. Retrieved from https://www.academia.edu/6855614/ Budaya_Instan_-_Bertahan_di_Tengah_Serbuan

Bleakley, P. (2014). "500 tokens to go private": Camgirls, cybersex and feminist entrepreneurship. Sexuality \& Culture, 18, 892-910. http://dx.doi.org/ 10.1007/ s12119-014-9228-3

Carnes, P. J., Delmonico, D. L., Griffin, E. J. (2007). In the shadows of the net: Breaking free of compulsive online sexual behavior (2nd ed.). Center City, MN: Hazelden Publishing.

Chen, S., Lee-Chai, A. Y., \& Bargh, J. A. (2001). Relationship orientation as a moderator of the effects of social power. Journal of Personality and Social Psychology, 80(2), 173-187. http://dx.doi.org/ 10.1037/0022-3514.80.2.173

Cooper, A., Delmonico, D. L., \& Berg, R. (2000). Cybersex users, abusers, and compulsives: New findings and implications. Sexual Addiction \& Compulsivity, 7(1-2), 5-29.

Daneback, K., Cooper, A., \& Månsson, S-A. (2005). An Internet study of cybersex participants. Archives of Sexual Behavior, 34, 321-328. http://dx.doi.org/ 10.1007/s10508-005-3120-z

DeLamater, J. D., \& Sill, M. (2005). Sexual desire in later life. Journal of Sex Research, 42(2), 138-149. http://dx.doi.org/10.1080/00224490509552267

Döring, N. (2000). Feminist views of cybersex: Victimization, liberation, and empowerment. CyberPsychology \& Behavior, 3(5), 863-884. http://dx.doi.org/10.1089/ 10949310050191845

Durex fundwear: A very strange cyber-sexual experiment. (2013). Retrieved from https://www.youtube.com/ watch?v=uIakRPPxTwM

Farrall, K. (2012). Online collectivism, individualism and anonymity in East Asia. Surveillance \& Society, 9(4), 424-440.

Garcia, E., \& Yang, K. C. C. (2006). Consumer responses to sexual appeals in cross-cultural advertisements. Journal of International Consumer Marketing, 19(2), 29-52.
Garlick, S. (2011). A new sexual revolution? Critical theory, pornography, and the Internet. Canadian Review of Sociology, 48(3), 221-239.

Gorman, S., Monk-Turner, E., \& Fish, J. N. (2010). Free adult Internet web sites: How prevalent are degrading acts? Gender Issues, 27, 131-145.

Griffin-Shelley, E. (2003). The Internet and sexuality: A literature review-1983-2002. Sexual and Relationship Therapy, 18(3), 355-370. http://dx.doi.org/ 10.1080/ 1468199031000153955

Grov, C., Gillespie, B. J., Royce, T., \& Lever, J. (2011). Perceived consequences of casual online sexual activities on heterosexual relationships: A U.S. online survey. Archives of Sexual Behavior, 40(2), 429-439. http://dx.doi.org/10.1007/ s10508010-9598-Z

Gul, M. C. (2013). Long-term orientation, perceived consumer effectiveness, and environmentally conscious consumer behavior: The case of Turkey. International Journal of Marketing Studies, 5(5), 24-30. http://dx.doi.org/10.5539/ ijms.v5n5p24

Hald, G. M., \& Malamuth, N. M. (2008). Self-perceived effects of pornography consumption. Archives of Sexual Behavior, 37, 614-625. http://dx.doi.org/ 10.1007/s10508-007-9212-1

Hamman, R. (1996). Cyborgasms: Cybersex among multiple-selves and cyborgs in the narrow-bandwidth space of America on-line chatrooms. (Unpublished dissertation). Department of Sociology, University of Essex, Colchester, UK.

Hatfield, E., Luckhurst, C., \& Rapson, R. L. (2010). Sexual motives: Cultural, evolutionary, and social psychological perspectives. Sexuality \& Culture, 14, 173-190.

Hofstede, G., Hofstede, G. J., \& Minkov, M. (2010). Cultures and organizations: Software of the mind (3rd ed.). USA: McGraw-Hill.

Jia, Y., van Lent, L., \& Zeng, Y. (2014). Masculinity, testosterone, and financial misreporting. Journal of Accounting Research, 52(5), 1195-1246. http://dx.doi. org/10.1111/1475-679X.12065

Jordan, J. V., Kaplan, A. G., Miller, J. B., Stiver, I. P., \& Surrey, J. L. (1991). Women's growth in connection: Writings from the Stone Center. New York: Guilford Press.

Kartajaya, H. (2006). Marketing in Venus playbook: Landscape in Venus (Vol. 1). Jakarta: Gramedia Pustaka Utama.

Kersten, G. E., Koeszegi, S. T., \& Vetschera, R. (2003). The effects of culture in computer-mediated negotiations. Journal of Information Technology Theory and Application, 5(2), 1-27. 
King, B. M. (2011). Human sexuality today (7th ed.). Upper Saddle River, NJ: Pearson Education.

Kirkman, B. L., Lowe, K. B., \& Gibson, C. B. (2006). A quarter century of "culture's consequences": A review of empirical research incorporating Hofstede's cultural values framework. Journal of International Business Studies, 37(3), 285-320.

Knox, D., \& Schacht, C. (2013). Choices in relationships: An introduction to marriage and the family (11th ed.). Belmont, CA: Wadsworth.

Leiblum, S. (2007). Principles and practice of sex therapy (4th ed.). Guilford Press, New York.

Levine, S. B. (2003). The nature of sexual desire: A clinician's perspective. Archives of Sexual Behavior, 32(3), 279-285. http://dx.doi.org/10.1023/A:1023421819465

Lippa, R. A. (2006). Is high sex drive associated with increased sexual attraction to both sexes? It depends on whether you are male or female. Psychological Science, 17, 46-52. http://dx.doi.org/10.1111/j.1467-9280. 2005.01663.x

Ly, A. (2013). A critical discussion of Hofstede's concept of Power Distance. Synaps, 28, 51-66.

Magnet, S. A. (2003). The persistence of gender, race and heterosexuality in cyberspace. (Unpublished dissertation). Ontario Institute for Studies in Education, University of Toronto, Canada.

McCallum, E. L. (1999). Mother talk: Maternal mas querade and the problem of the single girl. Camera Obscura, 14, (342), 70-95. http://dx.doi.org/10.DAA1215 /02705346-14-3_42-70

Michael, K. (2012, Spécial edition). Online sexual activities and sexual risk-taking among adolescents and young adults in Lagos Metropolis, Nigeria. African Journal of Reproductive Health, 16(2), 207-217.

Owens, E. W., Behun, R. J., Manning, J. C., \& Reid, R. C. (2012). The impact of Internet pornography on adolescents: A review of the research. Sexual Addiction \& Compulsivity, 19, 99-122.

Pagoto, S. (2012). Four things that undermine your willpower. Retrieved from https://www.psychology today.com/blog/shrink/201208/four-things-undermine -your-willpower

Pfaus, J. G., \& Scepkowski, L. A.. (2005). The biologic basis for libido. Current Sexual Health Reports, 2, 95-100. http://dx.doi.org/10.1007/s11930-005-0010-2

Potyrala, K. (2011). The impact of media culture on the biology education of "instant generation". Problems of Education in the 21st Century, 28, 96-105.

Rimington, D. D., \& Gast, J. (2007). Cybersex use and abuse: Implications for health education. American Journal of Health Education, 38(1), 34-40.
Rodríguez-Arauz, G., Mealy, M., Smith, V. \& Diplacido, J. (2013). Sexual behavior in Costa Rica and the United States. International Journal of Intercultural Relations, 37, 48-57. http://dx.doi.org/10.1016/j.ijintrel.2012.06.002

Ross, M. W., Rosser, B. R. S., \& Stanton, J. (2004). Beliefs about cybersex and Internet-mediated sex of Latino men who have Internet sex with men: Relationships with sexual practices in cybersex and in real life. AIDS Care, 16(8), 1002-1011. http:// dx.doi.org/10.1080/09540120412 331292444

Sajo, T. J. (2015). Mapping the affective production of cybersex: Notes for a framework. Graduate Journal of Social Science, 11(1), 77-92.

Schwartz, P., \& Rutter, V. (1998). The gender of sexuality. Thousand Oaks, CA: Pine Forge Press.

Seymen O. A., \& Bolat, O. I. (2010). The role of national culture in establishing an efficient safety culture in organizations: An evaluation in respect of Hofstede's cultural dimensions. Paper presented to Balikesir University, Turkey. Retrieved from http://w3.balikesir. edu.tr/ seymen/SeymenBolatAtina.pdf

Shaughnessy, K., \& Byers, E. S. (2013). Seeing the forest with the trees: Cybersex as a case study of single-item versus multi-item measures of sexual behavior. Canadian Journal of Behavioral Science, 45(3), 220-229. http://dx.doi.org/ 10.1037/a0031331

Shook, K. (2014). The Marshmallow Test: Understanding self-control and how to master it, by Walter Mischel. The Times Higher Education Supplement: THE 2170. Retrieved from http://www.timeshigher education.co.uk/books/the-marshmallow-testunderstanding-self-control- and-how-to-master-itby-walter-mischel/2015716.article

Snell, W. E., Jr. (2013). The Masculine Behavior Scale (MBS): Measurement instrument database for the social science. Retrieved from http://www.midss.org/sites/ default/files/mbs.pdf

Spector, I. P., Carey, M. P., \& Steinberg, L. (1996). The Sexual Desire Inventory: Development, factor, structure, and evidence of reliability. Journal of Sex \& Marital Therapy, 22, 175-190. http://dx.doi.org/10.1080/00 926 239608414655

Starcevic, V., \& Aboujaoude, E. (2015). Cyberchondria, cyberbullying, cybersuicide, cybersex: "New" psychopathologies for the 21st century? World Psychiatry 14(1), 97-100. http://dx.doi.org/10.1002/wps.20195

Štulhofer, A., Ferreira, L. C., \& Landripet, I. (2014). Emotional intimacy, sexual desire, and sexual satisfaction among partnered heterosexual men. Sexual and Relationship Therapy, 29(2), 229-244. http://dx.doi.org/10.1080/14681994. 2013.870335 
Swindler, S. D. (2007). A culturally sensitive examination of sexual harassment experiences, acknowledgment and measurement. (Unpublished dissertation). Southern Illinois University, Carbondale, US.

Tai, H. (2015, February 23). Indonesia's virginity tests: A growing women's right violation. Retrieved from $\mathrm{http} / / /$ internationalpoliticalforum.com/indonesiasvirginity-tests-a-growing-womens-rights-violation/

Tan, M. L. (2009). Reflections on digital ICTs, gender and sexuality in Asia. Retrieved from http://www. sxpolitics.org/wp-content/uploads/2009/04/reflections -on-digital-icts-gender-and-sexuality-in-asia_m-tan.pdf

Tong, S. T. (2008). Sorry, you're just not my type: Exploring romantic rejection in computer-mediated communication (Unpublished thesis). Michigan State University.

Ubillos, S., Páez, D. \& González, J. (2000). Culture and sexual behavior. Psicothema, 2, 70-82.

Webster, T. W. (2010). Pergaulan bebas and gendered youth culture in Yogyakarta, Indonesia. (Unpublished dissertation). University of Western Austalia. Retrieved from http://research-repository.uwa.edu.au/files/324580 9/ Wright_Webster_Tracy_2010.pdf

Weinstein. A. M., Zolek, R., Babkin, A., Cohen, K., \& Lejoyeux, M. (2015). Factors predicting cybersex use and difficulties in forming intimate relationships among male and female users of cybersex. Frontiers in Psychiatry, 6(54), 1-8. http://dx.doi.org/10.3389/ fpsyt .2015 .00054

Westrum, R., \& Adamski, A. J. (2010). Organizational factors associated with safety and mission success in aviation environments. In J. A. Wise, D. Hopkin, D. J. Garland (Eds.), Handbook of aviation human factors (2nd ed., pp. 5-1-5-33.). Boca Raton, FL: CRC Press.

Whitbourne, S. K. (2014). How women get addicted to cybersex. Retrieved from https://www.psychologytoday .com/blog/fulfillment-any-age/201408/how-womenget-addicted-cybersex

Williams, S., Lyons, L., \& Ford, M. (2008). It's about bang for your buck, Bro: Singaporean men's online conversations about sex in Batam, Indonesia. Asian Studies Review, 32, 77-97. http://dx.doi.org/10.1080/ 10357820701870767

Yoo, B., Donthu, N., \& Lenartowicz, T. (2011). Measuring Hofstede's five dimensions of cultural values at the individual level: Development and validation of CVSCALE. Journal of International Consumer Marketing, 23(3-4), 193-210

Young, K., Cooper, A., Griffin-Shelley, E., O’Mara, J., \& Buchanan, J. (2000). Cybersex and infidelity online: Implications for evaluation and treatment. Sexual Addiction and Compulsivity, 7(1), 59-74. Retrieved from http://netaddiction.com/articles/cyberaffairs.pdf 